Acta Horticulturae et Regiotecturae 1

Nitra, Slovaca Universitas Agriculturae Nitriae, 2017, pp. 15-18

\title{
SPATIAL ANALYSIS OF THE BIODEGRADABLE MUNICIPAL WASTE PRODUCTION AND DISPOSAL
}

\author{
Anna BÁREKOVÁ1* , Lenka LACKÓOVÁ', Bohdan STEJSKAL ${ }^{2}$ \\ 'Slovak University of Agriculture in Nitra, Slovak Republic \\ ${ }^{2}$ Mendel University in Brno, Czech Republic
}

\begin{abstract}
Separate collection of biodegradable municipal waste (BMW) is the main precondition to decrease the environmental pollution by landfill gas as well as to enrich soil by the humus substances from municipal compost. However, the obligation to ensure the separation and treatment of the BMW increases the municipalities' costs for waste management. Rural areas differ from the urban ones not only by typical lifestyle, settlement character, but also by total BMW production. The urban areas do have easier access to public finances, therefore, most of them already dispose sufficient infrastructure for BMW gathering and treatment. The aim of our research was to analyze the spatial production and disposal of the biodegradable municipal waste and propose, in regard to legislation, efficient BMW treatment for rural areas of the Nitra region. The analysis revealed that only $23 \%$ of the examined municipalities dispose through composting. However, $92 \%$ of them have the estimated annual BMW production from public green areas not exceeding 100t. Organic waste processing could be managed by municipalities through "small composting" which does not require the approval by the state body in waste management.
\end{abstract}

Keywords: biodegradable municipal waste, rural area, waste management, Nitra region

The Waste Management Plan of the Slovak Republic (SR) for 2016-2020 states that Slovakia fails in limitation of the BMW landfilling. Despite of large investments in infrastructure of processing facilities, the level of their recovery is still low. This program recommends, among others, to support domestic composting and to build small composting in those municipalities, for which such facilities are sufficient. The main reason is that the municipal structure of the Nitra region is rather fragmented and according to Fuka et al. (2016), in municipalities with up to 1,000 there live only $15.6 \%$ of citizens. BMW is defined the same way as the other biologically degradable waste, which can be classified as group 20 Communal Waste in the Waste Catalogue (decree No 365/2015 Coll.). According to the new Act No 79/2015 Coll., on waste, all the municipalities in Slovakia are obliged to ensure the separate collection on their own costs from the January 1, 2017 for the following BMW classes:

- BMW from households

- Edible oils and fats from households

- BMW from family houses' gardens

- BMW from public green areas - parks and cemeteries

The new waste management legislation governs that for the municipal areas, where over a half of citizens lives in houses with gardens, it is efficient to provide these houses with composting reservoirs. This principle ensures the fulfilment of not only the legal condition for separate collection of the BMW from gardeners but also separate collection of the household waste. If these rural areas all implemented the domestic composting, municipalities would need to treat the BMW from public green areas only.
A municipality can treat the BMW from public green areas in following ways:

1. Direct use on place of waste generation (e.g. mulching or communal composting),

2. Composting in the so called small (municipal) composting which recovers maximum 100t of BMW from public green areas annually and which does not require the consent by the state bodies for waste management,

3. Processing in facilities dedicated for recovery of more than 100t BMW annually, having the consent by the state body in waste management

The source segregation of biodegradable municipal waste (BMW) is also recommended by Dimambro et al. (2007). These authors compared ten source segregated BMW derived composts with two mixed municipal solid waste (MSW) derived composts. The authors found out that source segregated BMW composts had lower amounts of physical contaminants than MSW derived composts. Further data on physical contamination in MSW derived composts can be found elsewhere (Brinton, 2005; Montejo et al., 2015).

The proportion of BMW from households in MSW is about 25\% in rural areas (Báreková and Kaufman, 2012; Dobiašová et al., 2013). According to Eurostat, 2014, in Slovakia the average amount of composted MSW is only $6 \%$ (in the EU the average is 16\%) and in the Nitra region, $80 \%$ of MSW is landfilled (in the EU is $28 \%$ ).

The aim of the research was to analyse the spatial production and disposal of the BMW in regard to legislation using GIS (Muchová, 2016; Leitmanová, 2013) and more efficient BMW treatment in rural areas of the Nitra region. 
This type of analysis has not been performed before in the Nitra region.

\section{Material and methods}

In order to achieve our aim, it was necessary to conduct an analysis of the selected region, represented by the 339 municipalities with rural character placed in seven districts of the Nitra region. For each district, there were prepared tables and maps. The tables include the following information for each municipality:

A. Serial number.

B. Name of the municipality.

C. Number of citizens in the municipality (as for January 1, 2015).

D. Cadastral area of the municipality in hectares.

E. Public green area in the municipality in hectares.

F. Amount of the compost in tons, which can be used yearly, for maintenance and recovery of public green areas in the municipality.

G. Amount of annually processed BMW from green in tons, which is needed for generation of the required amount of compost.

$H$. Estimated annual production of the BMW from the given public green area of the municipality in tons.

The data in C, D and E columns were obtained from the Statistical Office of the SR databases (data on green public areas come from the Municipal statistics databases, last available year is 2012).

The data in $F$ column were calculated based on the recommended application of compost for public green areas maintenance (ME, 2008), where there is recommended to use the compost in the amount of up to $30 \mathrm{t}$ per hectare and this application must be repeated not earlier than three years after the previous application.

The data in $\mathrm{G}$ column is based on the assumption, that the weight of the final compost is $50 \%$ out of the original amount of the processed BMW. Hřebíček et al. (2010) proved the reduction of the weight by $40-60 \%$.

The data in $\mathrm{H}$ column is based on the assumption of annual production of BMW from green maintenance in the amount of 15t per hectare (Voštová and Altman, 2009). The already realized researches (Hřebíček et al.,
2010) proved the amount of BMW from public green maintenance from $4.5 \mathrm{t} \mathrm{ha}^{-1}$ to $16.5 \mathrm{t} \mathrm{ha}^{-1}$ per year.

The maps of the Nitra region district were processed in ArcMap 10.2.2 environment.

\section{Results and discussion}

The results of spatial analyses in the Nitra regions districts were the maps of the local municipalities (In the SR, the local municipalities are understood as villages, without the "town" status.) with the estimated annual production of BMW from public green areas up to 100 $\mathrm{t}$ (displayed in green colour) (Figrue 1). Cadastral areas of towns are displayed in white colour. Other municipalities are displayed shaded.
Based on the survey/monitoring, performed in September - November 2016, we identified the current situation in infrastructure for BMW recovery in the Nitra region. The obtained information were processed to maps and displayed in Figure 2.

It was found out that the total amount of the BMW which is being generated annually, from maintenance of public green areas, can be used for regular additional fertilization of these green areas after composting. It means that each municipality, which processes the waste from public green areas in their composting, can use these produced compost in public areas.

The Table 1 and Figure 1 display the processed data for each municipality in the Komárno district. Due to the limited

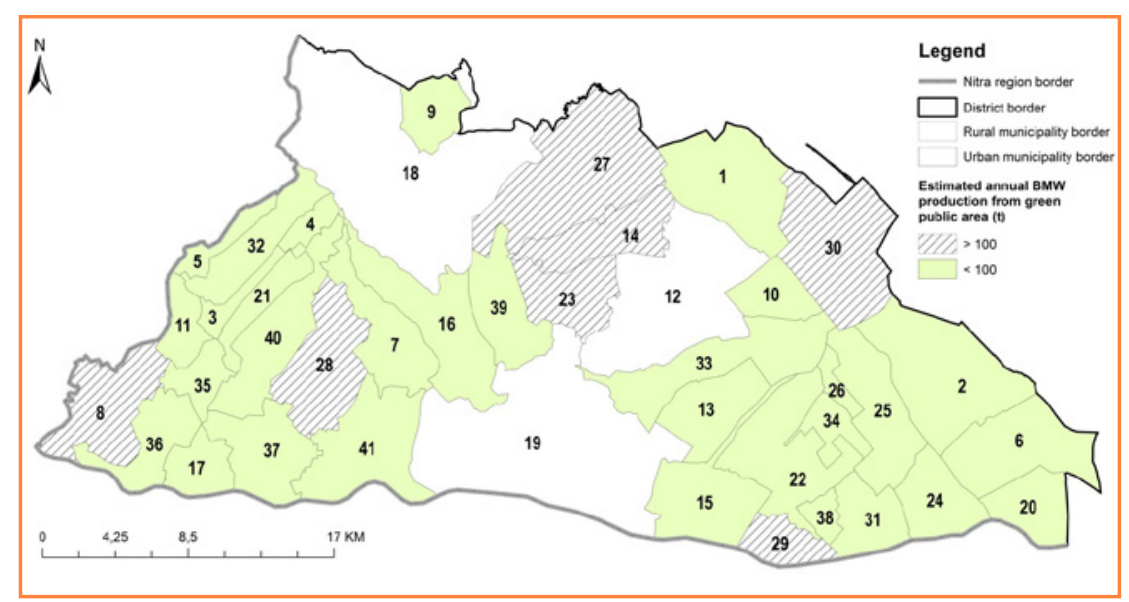

Figure 1 Annual BMW production in the Komárno district

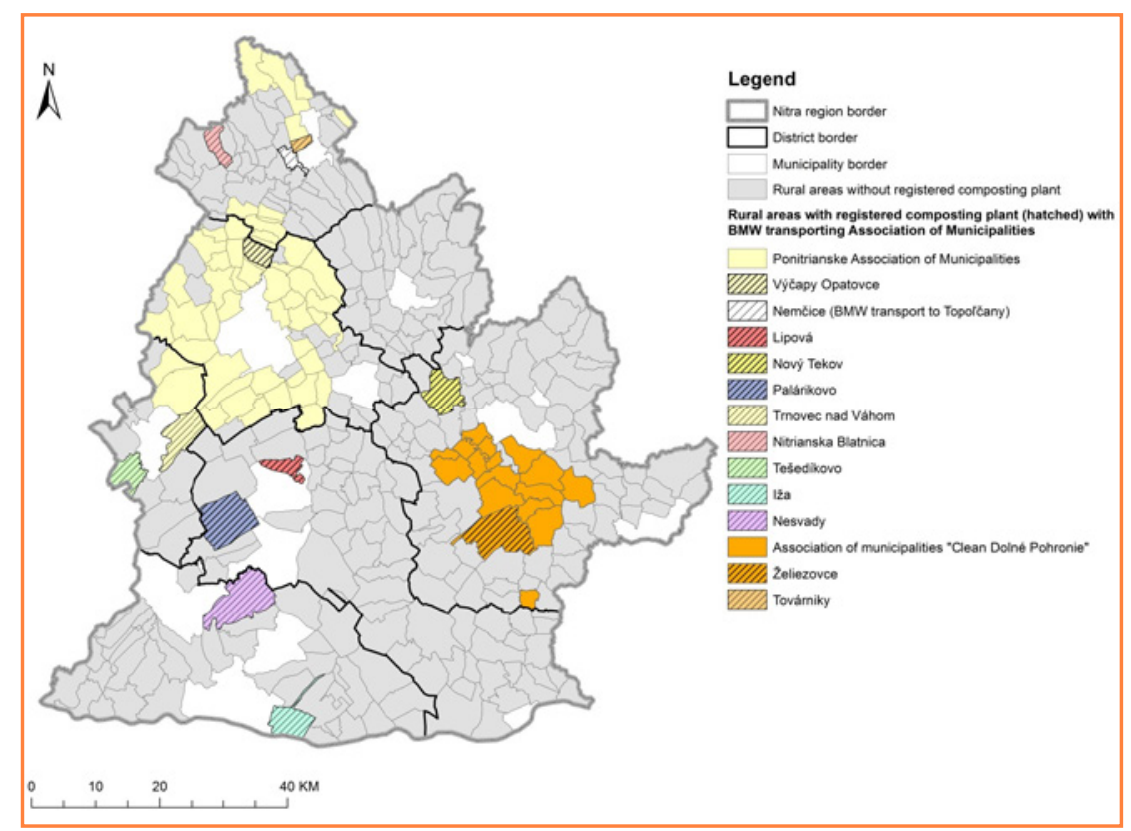

Figure 2 Composting in rural areas of the Nitra region conclusions 
Table 1 Processed data for Komárno district

\begin{tabular}{|c|c|c|c|c|c|c|c|}
\hline A & B & C & D & E & $\mathbf{F}$ & G & $\mathbf{H}$ \\
\hline 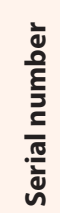 & 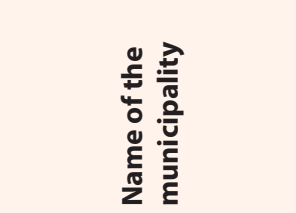 &  & 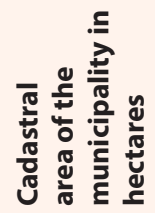 & 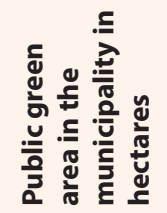 &  & 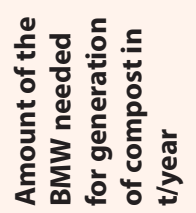 & 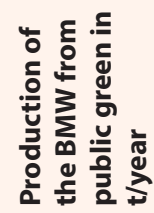 \\
\hline 1 & Bajč & 1,253 & $3,647.573$ & 1 & 10 & 20 & 15 \\
\hline 2 & Bátorove Kosihy & 3,399 & $4,588.552$ & 1.5 & 15 & 30 & 22.5 \\
\hline 3 & Bodza & 372 & 631.8239 & 3.66 & 36.6 & 73.2 & 54.9 \\
\hline 4 & Bodzianske Lúky & 191 & 516.6423 & 0.96 & 9.6 & 19.2 & 14.4 \\
\hline 5 & Brestovec & 504 & 749.1193 & 3.41 & 34.1 & 68.2 & 51.15 \\
\hline 6 & Búč & 1,151 & $3,150.094$ & 2.8 & 28 & 56 & 42 \\
\hline 7 & Čalovec & 1,164 & $2,320.865$ & 2.8 & 28 & 56 & 42 \\
\hline 8 & Číčov & 1,267 & $2,935.883$ & 15 & 150 & 300 & 225 \\
\hline 9 & Dedina Mládeže & 454 & $1,278.136$ & 1.5 & 15 & 30 & 22.5 \\
\hline 10 & Dulovce & 1,778 & $1,238.02$ & 2.32 & 23.2 & 46.4 & 34.8 \\
\hline 11 & Holiare & 493 & 988.4661 & 0.2 & 2 & 4 & 3 \\
\hline 12 & Hurbanovo & 7,605 & $5,993.932$ & 36.78 & 367.8 & 735.6 & 551.7 \\
\hline 13 & Chotín & 1,383 & $2,042.409$ & 1.5 & 15 & 30 & 22.5 \\
\hline 14 & Imel' & 1,960 & $2,195.95$ & 83.28 & 832.8 & 1665.6 & 1249.2 \\
\hline 15 & Iža & 1,636 & $2,801.897$ & 5 & 50 & 100 & 75 \\
\hline 16 & Kameničná & 1,929 & $3,451.219$ & 2.5 & 25 & 50 & 37.5 \\
\hline 17 & Klížska Nemá & 496 & $1,195.264$ & 2.52 & 25.2 & 50.4 & 37.8 \\
\hline 18 & Kolárovo & 10,632 & $10,682.28$ & 138.54 & 1385.4 & 2770.8 & 2078.1 \\
\hline 19 & Komárno & 34,461 & $10,316.77$ & 114 & 1140 & 2280 & 1710 \\
\hline 20 & Kravany nad Dunajom & 727 & $1,588.16$ & 1.8 & 18 & 36 & 27 \\
\hline 21 & Lipové & 145 & $1,057.841$ & 5.66 & 56.6 & 113.2 & 84.9 \\
\hline 22 & Marcelová & 3,764 & $3,574.957$ & 4.76 & 47.6 & 95.2 & 71.4 \\
\hline 23 & Martovce & 694 & $1,995.93$ & 17.2 & 172 & 344 & 258 \\
\hline 24 & Moča & 1,133 & $1,787.084$ & 1.05 & 10.5 & 21 & 15.75 \\
\hline 25 & Modrany & 1,407 & $2,706.567$ & 0.5 & 5 & 10 & 7.5 \\
\hline 26 & Mudroňovo & 130 & 400.6545 & 0.55 & 5.5 & 11 & 8.25 \\
\hline 27 & Nesvady & 5,100 & $5,786.658$ & 8.89 & 88.9 & 177.8 & 133.35 \\
\hline 28 & Okoličná na Ostrove & 1,512 & $2,988.994$ & 8.62 & 86.2 & 172.4 & 129.3 \\
\hline 29 & Patince & 471 & $1,131.544$ & 8.2 & 82 & 164 & 123 \\
\hline 30 & Pribeta & 2,901 & $4,279.541$ & 9.36 & 93.6 & 187.2 & 140.4 \\
\hline 31 & Radvaň nad Dunajom & 709 & $1,576.089$ & 2.32 & 23.2 & 46.4 & 34.8 \\
\hline 32 & Sokolce & 1,215 & $1,942.164$ & 4.4 & 44 & 88 & 66 \\
\hline 33 & Svätý Peter & 2,745 & $3,432.68$ & 4 & 40 & 80 & 60 \\
\hline 34 & Šrobárová & 508 & 838.7983 & 0.2 & 2 & 4 & 3 \\
\hline 35 & Tôň & 790 & 949.8558 & 0.4 & 4 & 8 & 6 \\
\hline 36 & Trávnik & 725 & $1,861.776$ & 0.2 & 2 & 4 & 3 \\
\hline 37 & Vel'ké Kosihy & 982 & $2,427.12$ & 3.17 & 31.7 & 63.4 & 47.55 \\
\hline 38 & Virt & 284 & 467.8863 & 5 & 50 & 100 & 75 \\
\hline 39 & Vrbová nad Váhom & 538 & $2,169.528$ & 0.02 & 0.2 & 0.4 & 0.3 \\
\hline 40 & Zemianska Olča & 2,362 & $2,794.216$ & 4.57 & 45.7 & 91.4 & 68.55 \\
\hline 41 & Zlatná na Ostrove & 2,390 & $3,530.963$ & 1 & 10 & 20 & 15 \\
\hline
\end{tabular}


scope of this article, we do not provide the tables and maps of the 6 remaining districts in the Nitra region (Levice, Nitra, Nové Zámly, Šala, Topoľčany, Zlaté Moravce). These data will be freely accessible at the website of the Horticulture and Landscape Engineering Faculty within the "Guideline for optimal treatment with the biologically degradable communal waste in rural areas of the Nitra region".

The Nitra region map displays the dispersion of composting (excluding the urban composting) in the Nitra region and its local municipalities, from which the BMW from green is transported for recovery (Fig. 2). In the Nitra region, neither a Biogas station nor composting for processing the waste from households are placed.

The analysis of the selected region represented by the Nitra rural areas showed that only $23 \%$ of the examined municipalities have the facilities for BMW recovery at their disposal. Therefore, our recommendations are dedicated mainly to those municipalities which do not dispose organic waste with efficient ways of treatment in regard to legislation.

The small size rural municipalities should focus on efficient use of processes leading to prevention of BMW generation, such as mulching and domestic and community composting in small size containers. The support shall include an intensive awareness program, training and practical services for citizens consisting in borrowing of garden crushers and mulching grass-cutters, promoting composting.

The base for fulfilment of the legislative requirements needs to be done by realizing of composting in each household and individual housing either by purchasing of new composters or by declaration of using the already existing ones. All the previously mentioned forms of prevention of waste generation have more advantages in comparison with the system of gathering and processing of BMW in composting. The municipalities release the obligation of recording and reporting the amount of collected BMW, there are no costs for the transport and processing and the soil is enriched by nutrients directly in the place of their generation. If a local municipality minimizes the generation of the BMW in such a way, only the waste from maintenance of the public green remains for processing and this can be even used in the total amount for regular additional fertilizing of green areas (without the need of compost certification as fertilizer). The Nitra region analysis and public green area analysis in different local municipalities show that $92 \%$ of rural areas in the Nitra region (312 local municipalities out of the total amount of 339) have estimated the annual production of BMW from public green not exceeding 100 tons. This means that their processing can be performed in so called "small composting" which does not require the state body in waste management consent and their operation is a subject to less strict requirements as it is in the case of facilities with the capacity of recovery over 100t BMW per year. In case there is no composting close to a local municipality, able to regularly receive and process waste from public green at adequate fees, it is advisable to establish a small local composting, serving even more rural municipalities. Most of the investment costs for construction and provision of the necessary technology can be received by grants from the Environmental Fund or from the Operational Program Quality of the Environment.

\section{Acknowledgment}

This paper was supported by the EEA and Norway grants "BFB-PA21-004 - Green Industry Innovation (GII)".

\section{References}

BÁREKOVÁ, A. - KAUFMAN, P. 2012. Návrh modelového zloženia TKO vo vidieckej zástavbe. In Acta horticulturae et regiotecturae, roč. 15, 2012, mimoriadne číslo, s. 13-15. ISSN 1335-2563. Dostupné na internete: $<$ http://www.fem.uniag.sk/acta/download. php?id=1085>

BRINTON, W. F. 2005. Characterization of man-made foreign matter and its presence in multiple size fractions from mixed waste composting. In Compost Sci. Util., vol. 13, 2005, no. 4, pp. 274-280. DIMAMBRO, M. E. - LILLYWHITE, R. D. - RAHN, C. R. 2007. The physical, chemical and microbial characteristics of biodegradable municipal waste derived composts. In Compost Sci. Util., vol. 15, 2007, no. 4, pp. 243-252.

DOBIAŠOVÁ, D. - TÁTOŠOVÁ, L. - KVOKAČKA, J. - NOVOTNÁ, B. 2013. Analýza tuhých komunálnych odpadov vo vidieckej zástavbe. 1. vyd. In ENVIRO 2013, CD-ROM, 2013. s. 41-54. ISBN 978-80-552-1101-5.

FUKA, J. - GREŠOVÁ, L. - SATERA, K. 2016. Differences in Municipal Structure in Czech and Slovak Republic with Emphasis on Delegated Powers. 27 $7^{\text {th }}$ International Business Information Management Association Conference Location: Milan, Italy. May 04-05, 2016. In: Innovation Management and Education Excellence Vision 2020: From Regional Development Sustainability To Global Economic Growth, vol. 6, 2016, pp. 252-261.

HŘEBÍČEK, J. - PILIAR, F. - KALINA, J. - MANHART, J. - SOUČKOVÁ, K. 2010. Projektování nakládání s bioodpady v obcích. Brno : Littera. 101 p. ISBN 978-80-85763-56-0.

LEITMANOVÁ, M. - MUCHOVÁ, Z. - STREĎANSKÁ, A. 2013. Concept of information system for land consolidation projects. In Acta horticulturae et regiotecturae, vol. 16, 2013, no. 2, pp. 40-43. ISSN 1335-2563. Dostupné na internete: <http://www.degruyter. com/view/j/ahr.2013.16.issue-2/ahr-2013-0010/ahr-2013-0010. xml?format $=$ INT $>$

MONTEJO, C. - COSTA, C. - MÁRQUEZ, M. C. 2015. Influence of input material and operational performance on the physical and chemical properties of MSW compost. In J. Environ. Manage., 162, 2015, pp. 240-249.

MUCHOVÁ, Z. - LEITMANOVÁ, M. 2016. The register suggestions: processing tool for land consolidation project. In Acta horticulturae et regiotecturae, vol. 19, 2016, no. 2, pp. 32-36. ISSN 1335-2563.

MŽP ČR. 2008. Metodický návod o podrobnostech nakládání $s$ biologicky rozložitelnými odpady podle stávajících právních předpisů. 8.12.2008 Available on: <http://www.mzp.cz/cz/ nakladani_s_biologicky_rozlozitelnymi_odpady_metodika>

VOŠTOVÁ, V. - ALTMAN, V. 2009. Logistika odpadového hospodářství. Praha : České vysoké učení technické, 2009. 349 p. ISBN 978-80-01-04426-1.

VYHLÁŠKA č. 365/2015 Z. z. Ministerstva životného prostredia Slovenskej republiky z 13. novembra 2015, ktorou sa ustanovuje Katalóg odpadov.

ZÁKON č. 79/2015 Z. z. o odpadoch a o zmene a doplnení niektorých zákonov. 